Jurnal Info Kesehatan

Vol. 19, No. 2. December 2021, pp. 110-124

P-ISSN 0216-504X, E-ISSN 2620-536X

DOI: 10.31965/infokes.Vol19Iss2.518

Journal homepage:http://jurnal.poltekeskupang.ac.id/index.php/infokes

RES E A R C H

Open Access

\title{
The Influence of Perceptions of Social Support and Family Health Tasks on HIV/AIDS Prevention Behavior in Adolescents
}

\author{
Diah Ratnawati ${ }^{1{ }^{*}}$, Nourmayansa Vidya Anggraini ${ }^{1 \mathrm{~b}}$ \\ ${ }^{1}$ Program Study of Nursing Profession, Faculty of Health Science, Universitas Pembangunan \\ Nasional Veteran Jakarta, Jakarta, Indonesia. \\ ${ }^{a}$ Email address: ratnawatidiah@yahoo.co.id \\ b Email address: nourmayansa.vidya @gmail.com
}

Received: 13 April 2021

Revised: 25 April 2021

Accepted: 21 July 2021

\begin{abstract}
Adolescents are physically and psychologically vulnerable to the transmission of HIV/AIDS, so that they become the focus of the population for disease prevention programs. This study aims to determine the effect of perceptions of social support and family health tasks on HIV/AIDS prevention behavior in adolescents in Baros Village, Serang, Banten. This study employed a quantitative research method with a cross-sectional design. The number of samples was 345 adolescents who were at risk of HIV/AIDS in Baros Village, Serang, Banten. Sampling from each class administering stratified sampling method. Researchers reproduced research questionnaires with an offline system which had previously been examined for the validity and reliability of a number of samples that have been calculated. Furthermore, for research questionnaires with an online system, distribution is conducted via a link from the google form. The chi-square test was administered to examine HIV/AIDS prevention behavior variables. A logistic regression test was used to see the most influential factors on HIV/AIDS prevention behavior. The results revealed a relationship between gender and family health tasks in recognizing HIV/AIDS prevention behavior problems in adolescents in Baros Village, Serang, Banten, with a p-value $<0.05$. The factor that most influenced HIV/AIDS prevention behavior was the family health task in recognizing problems with a p-value of $0.007<0.05$ with the largest OR value obtained, which is 1.978 . Therefore, families should improve their ability to conduct health tasks in communicating and directing adolescents in HIV/AIDS prevention behavior.
\end{abstract}

Keywords: Adolescents, HIV/AIDS, Family Health Tasks.

*Corresponding Author:

Diah Ratnawati

Program Study of Nursing Profession, Faculty of Health Science, Universitas Pembangunan Nasional Veteran Jakarta, Jakarta, Indonesia.

Email: ratnawatidiah@yahoo.co.id

(CThe Author(s) 2021. This article is distributed under the terms of the Creative Commons Attribution 4.0 International License (http://creativecommons.org/licenses/by/4.0/), which permits unrestricted use, distribution, and reproduction in any medium, provided you give appropriate credit to the original author(s) and the source, provide a link to the Creative Commons license, and indicate if changes were made. The Creative Commons Public Domain Dedication waiver (http://creativecommons.org/publicdomain/zero/1.0/) applies to the data made available in this article, unless otherwise stated. 


\section{INTRODUCTION}

According to the World Health Organization, (2012), adolescents are residents in the age range of 10-19 years. The Regulation of the Minister of Health of the Republic of Indonesia Number 2005 of 2014 states that adolescents are residents in the age range of 10-18 years, while from the Population and Family Planning Agency (BKKBN), the age range of adolescents is 10-24 years and unmarried (Kementerian Kesehatan Republik Indonesia, 2014). The number of adolescents in Indonesia is $17 \%$ of the entire population of Indonesia (Kementerian Kesehatan Republik Indonesia., 2018). In Banten Province, adolescents reached $3,435,822$ people or $29.07 \%$ of the total population in Banten (Dinas Kesehatan Provinsi Banten, 2011). This large population of teenagers is a great resource for administering development to realize an advanced, independent, competitive, prosperous and moral Banten in accordance with the vision of the Banten Provincial Government.

However, adolescents generally possess an unbalanced emotional turmoil. Thus, they are easily affected by the influence of the environment. The phenomenon of adolescent health problems if not treated can increase the disease Human Immunodeficiency Virus/HIV and Acquired Immunodeficiency Syndrome/AIDS which is a disease that continues to grow and become a global problem in the world. The incidence of HIV/AIDS is a concern in the Sustainable Development Goals (SDGS), which is stated in the third goal.

Based on data from the Directorate General of P2PL (Disease Control and Environmental Health), statistics on HIV/AIDS cases reported from 2011-2012 have increased, which is in 2011, new cases of HIV were 21,031 cases, then increased to 21,511 cases in 2012. Likewise with AIDS from 2011, it was 37,201 cases, increasing to 42,887 cases in 2012. The proportion of risk factors for HIV/AIDS sufferers through heterosexual intercourse is the mode of transmission with the highest percentage at $77.75 \%$, followed by IDUs or injecting drug users (IDU) at $9.16 \%$ and from mother to child by $3.76 \%$ (Kementerian Kesehatan Republik Indonesia, 2014).

The Adolescent Reproductive Health Program is integrated into the Adolescent Health Program in Indonesia. The Youth Care Health Program (PKPR) has been launched since 2003 . For more than ten years, this program has been mostly engaged in providing information, in the form of lectures, questions and answers with youth about health problems through the School Health Business (UKS), Karang Taruna (Youth Organization), or other youth organizations and other youth cadres formed by the Puskesmas (Primary Health Center). PKPR activities are in the form of health services for adolescents that access all groups of adolescents, which are acceptable, appropriate, comprehensive, effective and efficient. Banten Province is a province with HIV/AIDS cases with low knowledge of HIV/AIDS prevention in Indonesia (Kementerian Kesehatan Republik Indonesia., 2018). Thus, Banten is an area that requires efforts to prevent and control HIV/AIDS through health education and healthy life skills for its youth. Information about the knowledge, attitudes, and behavior of adolescents is needed to design these prevention and control efforts.

Teenagers spend a lot of time interacting in peer groups. It identifies that the existence of peers is tremendously important for adolescents. Data in Serang District shows that adolescents aged 12-18 years, 16\% received information about sex from friends, 35\% from pornographic films, and only 5\% from parents (Dinas Kesehatan Provinsi Banten, 2011). Hence, in their development period, adolescents require an adaptive social environment so that they are able to create comfortable conditions for asking questions and forming a responsible character for themselves. Adolescents are 
also physically and psychologically vulnerable to the transmission of HIV/AIDS. Thus, adolescents are the focus of the population of this disease prevention program. Baros Village, Serang is in the area of the Banten Provincial Health Office where Banten Province is a province with HIV/AIDS cases with low knowledge of HIV/AIDS prevention in Indonesia (Kementerian Kesehatan Republik Indonesia., 2018). Therefore, it is important to know "The influence of perceptions of social support and family health tasks on HIV/AIDS prevention behavior in adolescents in Baros Village, Serang, Banten." Hence, the right health program strategy is implemented in the area.

\section{RESEARCH METHOD}

This research is a quantitative study, employing a descriptive analytic design with a cross-sectional research method. The population in this study were all adolescent age groups who attended SMAN 1 Baros Serang and SMK/SMA Attaufiqiyyah and were in Baros Village, Serang, Banten. Sampling from each class administering stratified sampling method. After calculating the number of samples obtained as many as 345 teenagers to anticipate dropouts, the researchers added as much as $10 \%$ of the total sample so that the total became 380 samples.

This study employed univariate analysis to find the demographic values of the respondents (frequency distribution of age, gender, parental education, parental occupation, family income level, living in the same house, and ethnicity). Furthermore, univariate analysis is also utilized to identify the value of family structure, social culture, perceptions of social support, and family health tasks. Bivariate analysis used was the Chi-Square Test Formula to determine whether there was a relationship between age, gender, parental education, parental occupation, family income level, living in the same house, ethnicity, social culture, perception of social support, family structure, function and family health tasks. Multivariate analysis was performed employing the logistic regression test formula to identify the most influential factors on HIV/AIDS prevention behavior. This research has passed the ethical test from the UPNV Health Research Ethics Committee Number 2672/VII/2020/KEPK.

\section{RESULTS AND DISCUSSION}

Table 1. Demographic Frequency Distribution in Baros Village, Serang, Banten.

\begin{tabular}{lrr}
\hline Variable & Frequency & Percentage (\%) \\
\hline Age & & \\
\hline Middle Ages (14-16 years) & 267 & 77,4 \\
\hline Late Adolescence (17-20 years) & 78 & 22,6 \\
\hline Gender & 197 & 57,1 \\
\hline Woman & 148 & 42,9 \\
\hline Man & 300 & 87 \\
\hline Father's Education & & 13 \\
\hline $\begin{array}{l}\text { Low Education (No School/Not Finished } \\
\text { Elementary/SD/SMP) }\end{array}$ & 45 & \\
\hline $\begin{array}{l}\text { Higher Education } \\
\text { (SMA/Diploma/Bachelor/Postgraduate }\end{array}$ & & 92,2 \\
\hline Mother's Education & 318 & 7,8 \\
\hline $\begin{array}{l}\text { Low Education (No School/Not Finished } \\
\text { Elementary/SD/SMP) }\end{array}$ & 27 & \\
\hline $\begin{array}{l}\text { Higher Education } \\
\text { (SMA/Diploma/Bachelor/Postgraduate }\end{array}$ & &
\end{tabular}


Ratnawati, D., \& Anggraini, N. V. (2021). The Influence of Perceptions of Social Support and Family Helath

\begin{tabular}{|c|c|c|}
\hline \multicolumn{3}{|l|}{ Father's occupation } \\
\hline Civil servant & 6 & 1,7 \\
\hline Non civil servant & 339 & 98,3 \\
\hline \multicolumn{3}{|l|}{ Mother's Job } \\
\hline Civil Servant & 2 & 0,6 \\
\hline Non Civil Servant & 343 & 99,4 \\
\hline \multicolumn{3}{|l|}{ Ethnic group } \\
\hline Java & 10 & 2,9 \\
\hline Sunda & 110 & 31,9 \\
\hline Betawi & 2 & 0,6 \\
\hline Other & 223 & 64,6 \\
\hline \multicolumn{3}{|l|}{ Family Income } \\
\hline Less (< Rp. 3,872,551.00) & 323 & 93,6 \\
\hline More (> IDR 3,872,551.00) & 22 & 6,4 \\
\hline \multicolumn{3}{|l|}{ Family Structure } \\
\hline Nuclear family (father-mother-child) & 298 & 86,4 \\
\hline $\begin{array}{l}\text { Single parent (lives only with } \\
\text { father/mother) }\end{array}$ & 6 & 1,7 \\
\hline Family of three generations & 20 & 5,8 \\
\hline Extended family & 21 & 6,1 \\
\hline
\end{tabular}

Table 1 above shows that more than half of the teenagers in Baros Village, Serang, Banten in 2020 were the middle group of 267 people $(77.44 \%)$, while the late teens group was 78 people $(22.6 \%)$. In conclusion, most of the teenagers in Baros Village, Serang, Banten are middle teens (14-16 years). More than half of adolescents in Baros Village, Serang, Banten in 2020 were female, which were 197 people (57.1\%), while adolescents with male sex were 148 people $(42.9 \%)$. The majority of fathers and mothers have low education (no school/did not finish elementary/elementary/junior high school). The work of the father and mother are mostly non civil servants. Based on ethnicity among adolescents in Baros Village, Serang are mostly ethnic groups other than Javanese, Sundanese, Betawi. Most of the family income is less than the UMK (Minimum Wage), which is Rp. 3,872,551.00. Most teenagers live with their father and mother, which are included in the nuclear family structure.

Table 2. Frequency Distribution Based on Perceived Social Support, Family Health Tasks, and HIV/AIDS Prevention Behavior in Adolescents in Baros Village, Serang, Banten.

\begin{tabular}{lcc}
\hline Variable & Frequency & Percentage (\%) \\
\hline $\begin{array}{l}\text { Perception of Social Support } \\
\text { Negative Perception of Social }\end{array}$ & 167 & 48,4 \\
$\begin{array}{l}\text { Support } \\
\text { Positive Perception of Social } \\
\text { Support }\end{array}$ & 178 & 51,6 \\
\hline Families Recognize HIV/AIDS Problems & & \\
\hline Unable to recognize the problem & 141 & 40,9 \\
\hline Able to recognize problems & 204 & 59,1 \\
\hline Family Makes Decision & & 48,4 \\
\hline Unable to make a decision & 167 & 51,6 \\
\hline Able to make decisions & 178 &
\end{tabular}




\section{Family Caring for Sick Family Members}

Unable to care for sick family 181

members

Able to care for sick family

164

47,5

members

Family Modifies Environment

\begin{tabular}{lll}
\hline Unable to modify the environment & 153 & 44,3 \\
\hline Able to modify the environment & 192 & 55,7 \\
\hline
\end{tabular}

\section{Families Use Health Services}

Unable to take advantage of health

216

62,6

services

Able to take advantage of health

129

37,4

services

\section{Implementation of Family Health}

Tasks

\begin{tabular}{lrc}
\hline $\begin{array}{l}\text { Unable to conduct family health } \\
\text { duties }\end{array}$ & 184 & 53,3 \\
\hline Able to perform family health tasks & 161 & 46,7 \\
\hline HIV/AIDS Prevention Behavior & 255 & 73,9 \\
\hline Good Behavior & 90 & 26,1 \\
\hline Bad Behavior
\end{tabular}

In table 2, as many as $48.4 \%$, which were 167 people had negative perceptions and $51.6 \%$, which were 178 people possessed positive perceptions. Family health assignments based on the ability of families to recognize problems showed that most of the adolescents, who were 204 families (59.1\%) of adolescents in Baros Village, Serang, Banten were able to recognize problems. Family health tasks based on the ability of families to make decisions show the results of most families as many as 178 families (51.6\%). There were teenagers in Baros Village, Serang, Banten able to make decisions for their teenagers. Regarding the task of family health in caring for sick members, the results presented that 181 families (52.5\%) of adolescents in Baros Village, Serang, Banten were unable to care for sick family members.

The task of family health related to the ability of families to modify the environment that as many as $153(55.7 \%)$ families of adolescents in Baros Village, Serang, Banten were able to modify an appropriate environment for their adolescent children so that they were able to perform HIV/AIDS prevention behavior. Although overall, the implementation of family health tasks is still a lot, a number of 184 families (53.3\%) are unable to perform family health tasks. The description of HIV/AIDS prevention behavior in the table above, as many as $73.9 \%$, which were 255 people, most of whom are teenagers who show good behavior.

Table 3. Analysis of Demographic Relationships with HIV/AIDS Prevention Behavior in Adolescents in Baros Village, Serang, Banten.

\begin{tabular}{|c|c|c|c|c|c|c|c|}
\hline \multirow[t]{3}{*}{ Variable } & \multicolumn{5}{|c|}{ HIV/AIDS Prevention Behavior } & \multirow{3}{*}{$\begin{array}{c}p- \\
\text { value }\end{array}$} & \multirow[t]{3}{*}{ OR } \\
\hline & \multicolumn{2}{|c|}{$\begin{array}{c}\text { Good } \\
\text { Behavior }\end{array}$} & \multicolumn{2}{|c|}{$\begin{array}{l}\text { Bad } \\
\text { Behavior }\end{array}$} & Total & & \\
\hline & $\mathbf{n}$ & $\%$ & $\mathbf{n}$ & $\%$ & n $\%$ & & \\
\hline \multicolumn{8}{|l|}{ Age } \\
\hline $\begin{array}{l}\text { Middle Ages (14-16 } \\
\text { years) }\end{array}$ & 202 & 76 & 65 & 24 & 26777,4 & 0,224 & $\begin{array}{c}1,466 \\
(0,844-2,545)\end{array}$ \\
\hline
\end{tabular}


Ratnawati, D., \& Anggraini, N. V. (2021). The Influence of Perceptions of Social Support and Family Helath

Tasks on HIV/AIDS Prevention Behavior in Adolescents. JURNAL INFO KESEHATAN, 19(2), 110-124. https://doi.org/10.31965/infokes.Vol 19/ss2.518

1115

\begin{tabular}{lllllll}
\hline Late Adolescence & 53 & 68 & 25 & 32 & 78 & 22,6
\end{tabular}

(17-20 years)

\section{Gender}

Woman

$\begin{array}{lllllll}155 & 78,7 & 42 & 21,3 & 197 & 57,1 & 0,028\end{array}$

1,771

Man

$\begin{array}{llllll}100 & 67,6 & 48 & 32,4 & 148 & 42,9\end{array}$

Father's education

Low education (No

$219 \quad 73 \quad 81$

$81 \quad 27$

$27 \quad 300$

87

0,415

0,676

school/Not finished

elementary

school/elementary/

junior high school)

Higher Education

$\begin{array}{llllll}36 & 80 & 9 & 20 & 45 & 13\end{array}$

(SMA/Diploma/Bac

helor/Postgraduate)

\section{Mother's}

\section{Education}

\begin{tabular}{lcccccccc}
\hline $\begin{array}{l}\text { Low education (Not } \\
\text { in school/Not } \\
\text { graduated from }\end{array}$ & 234 & 73,6 & 84 & 26,4 & 318 & 92,2 & 0,804 & $\begin{array}{r}0,796 \\
(0,311- \\
2,039)\end{array}$ \\
$\begin{array}{l}\text { SD/SD/SMP) } \\
\begin{array}{l}\text { Higher Education } \\
\text { (SMA/Diploma/Bac }\end{array}\end{array}$ & 21 & 77,8 & 6 & 22,2 & 27 & 7,8 & & \\
helor/Postgraduate) & & & & & & & & \\
\hline
\end{tabular}

\section{Ethnic group}

\begin{tabular}{|c|c|c|c|c|c|c|c|}
\hline Java & 5 & 50 & 5 & 50 & 10 & 2,9 & 0,222 \\
\hline Sunda & 85 & 77,3 & 25 & 22,7 & 110 & 31,9 & \\
\hline Betawi & 2 & 100 & 0 & 0 & 2 & 0,6 & \\
\hline Other & 164 & 73,1 & 60 & 26,9 & 223 & 64,6 & \\
\hline
\end{tabular}

\section{Family income}

Less $(<\mathrm{Rp}$.

$73,7 \quad 85 \quad 26,3 \quad 323$

$93,6 \quad 0,904$

0,824

3,872,551.00) 238

More $(\geq \mathrm{Rp}$.

3,872,551.00)

17

$\begin{array}{lllll}77,3 & 5 & 22,7 & 22 & 6,4\end{array}$

$(0,295$ -

\section{Family Structure}

Nuclear Family

$\begin{array}{llllll}220 & 73,8 & 78 & 26,2 & 298 & 100\end{array}$

(Father-Mother-

Child)

Single Parent

$\begin{array}{llllll}5 & 83,3 & 1 & 16,7 & 6 & 100\end{array}$

(Lives Only With

Father/Mother)

Family of 3

$\begin{array}{lllllll}15 & 75 & 5 & 25 & 20 & 100 & 0,949\end{array}$

generations

(Three generation)

Extended family

$\begin{array}{llllll}15 & 71,4 & 6 & 26,6 & 21 & 100\end{array}$

Table 3 shows that there is no significant relationship between age and HIV/AIDS prevention behavior in adolescents in Baros Village, Serang, Banten. However, there is a significant relationship between gender and HIV/AIDS prevention behavior in 
adolescents in Baros Village, Serang, Banten. However, in the table, it is displayed that there is no significant relationship between father and mother's education with HIV/AIDS prevention behavior in adolescents in Baros Village, Serang, Banten. There is no significant relationship between father and mother's work with HIV/AIDS prevention behavior in adolescents in Baros Village, Serang, Banten. There is no relationship between ethnicity and HIV/AIDS prevention behavior in adolescents in Baros Village, Serang, Banten. There is no relationship between family income and HIV/AIDS prevention behavior in adolescents in Baros Village, Serang, Banten, and there is no relationship between family structure and HIV/AIDS prevention behavior in adolescents in Baros Village, Serang, Banten.

Table 4. Analysis of the Relationship between Perceptions of Social Support and Family Health Tasks with HIV/AIDS Prevention Behavior in Adolescents in Baros Village, Serang, Banten.

\begin{tabular}{|c|c|c|c|c|c|c|c|c|}
\hline \multirow{3}{*}{ Variable } & \multicolumn{6}{|c|}{ HIV/AIDS Prevention Behavior } & \multirow[t]{3}{*}{$\begin{array}{l}p \text { - } \\
\text { value }\end{array}$} & \multirow[t]{3}{*}{ OR } \\
\hline & \multicolumn{2}{|c|}{$\begin{array}{c}\text { Good } \\
\text { Behavior }\end{array}$} & \multicolumn{2}{|c|}{$\begin{array}{c}\text { Bad } \\
\text { Behavior }\end{array}$} & \multicolumn{2}{|c|}{ Total } & & \\
\hline & $\mathbf{n}$ & $\%$ & $\mathbf{n}$ & $\%$ & $\mathbf{N}$ & $\%$ & & \\
\hline \multicolumn{9}{|c|}{ Perception of Social Support } \\
\hline $\begin{array}{l}\text { Negative Perception } \\
\text { of Social Support }\end{array}$ & 123 & 73,7 & 44 & 26,3 & 167 & 100 & \multirow{2}{*}{1,000} & $\begin{array}{l}0,974 \\
(0,602\end{array}$ \\
\hline $\begin{array}{l}\text { Positive Perception } \\
\text { of Social Support }\end{array}$ & 132 & 74,2 & 46 & 25,8 & 178 & 100 & & $\begin{array}{l}- \\
1,576)\end{array}$ \\
\hline \multicolumn{9}{|c|}{ Family Health Tasks Recognize Problems } \\
\hline Not capable & 94 & 66,7 & 47 & 33,3 & 141 & 100 & \multirow[t]{2}{*}{0,015} & 0,534 \\
\hline Capable & 161 & 78,9 & 43 & 21,1 & 204 & 100 & & $\begin{array}{l}(0,329 \\
- \\
0,868)\end{array}$ \\
\hline \multicolumn{9}{|c|}{ Family Health Tasks make decisions } \\
\hline Not capable & 121 & 72,5 & 46 & 27,5 & 167 & 100 & \multirow{3}{*}{0,635} & 0,864 \\
\hline Capable & 134 & 75,3 & 44 & 24,7 & 178 & 100 & & $(0,534$ \\
\hline & & & & & & & & $\begin{array}{l}- \\
1,397)\end{array}$ \\
\hline \multicolumn{9}{|c|}{ Family Health Tasks Caring for Sick Family Members } \\
\hline Not capable & 134 & 74 & 47 & 26 & 181 & 100 & & 1,013 \\
\hline Capable & 121 & 73,8 & 43 & 26,2 & 164 & 100 & 1,000 & $\begin{array}{l}(0,626 \\
- \\
1,639)\end{array}$ \\
\hline \multicolumn{9}{|c|}{ Family Health Tasks Modifying the Environment } \\
\hline Not capable & 108 & 70,6 & 45 & 29,4 & 153 & 100 & & 0,735 \\
\hline Capable & 147 & 76,6 & 45 & 23,4 & 192 & 100 & 0,258 & $\begin{array}{l}(0,454 \\
- \\
1,190)\end{array}$ \\
\hline \multicolumn{9}{|c|}{ Family Health Tasks Utilizing Health Services } \\
\hline Not capable & 154 & 71,3 & 62 & 28,7 & 216 & 100 & & 0,689 \\
\hline Capable & 101 & 78,3 & 28 & 21,7 & 129 & 100 & 0,192 & $\begin{array}{l}(0,413 \\
- \\
1,149)\end{array}$ \\
\hline
\end{tabular}




\begin{tabular}{|c|c|c|c|c|c|c|c|c|}
\hline \multicolumn{9}{|c|}{ Implementation of Family Health Tasks } \\
\hline $\begin{array}{l}\text { Unable to carry } \\
\text { out }\end{array}$ & 130 & 70,7 & 54 & 29,3 & 184 & 100 & \multirow{2}{*}{0,176} & $\begin{array}{l}0,693 \\
(0,426\end{array}$ \\
\hline Able to carry out & 125 & 77,6 & 36 & 22,4 & 161 & 100 & & $\begin{array}{l}- \\
1,129)\end{array}$ \\
\hline
\end{tabular}

Based on table 4, there is no significant relationship between perceived social support and HIV/AIDS-AIDS prevention behavior in adolescents in Baros Village, Serang, Banten. Likewise, presented in the table, there is no significant relationship between family health tasks and HIV/AIDS prevention behavior in adolescents in Baros Village, Serang, Banten.

Table 5. Feasibility Analysis of Independent Variables for Multivariate Test Model.

\begin{tabular}{lr}
\hline Sub Variable & $\boldsymbol{p}$-value \\
\hline Family ability to recognize problems & 0,015 \\
\hline Family decision-making ability & 0,902 \\
\hline Ability of the family to care for sick family members & 0,537 \\
\hline Family's ability to modify the environment & 0,303 \\
\hline Ability of families to use health facilities & 0,395 \\
\hline Implementation of Family Health Tasks & 0,139 \\
\hline Perception of social support & 0,873 \\
\hline Age & 0,360 \\
\hline Gender & 0,024 \\
\hline Father's education & 0,711 \\
\hline Mother's education & 0,798 \\
\hline Father's occupation & 0,859 \\
\hline Mother's work & 0,999 \\
\hline Family income & 0,940 \\
\hline Ethnic group & 0,737 \\
\hline Family structure & 0,993 \\
\hline
\end{tabular}

Multivariate analysis was performed on independent variables including: age, gender, parental education (father and mother), parental occupation (father and mother), ethnicity, family income, family structure, perception of social support, family health tasks (family ability to recognize problems, the ability of the family to make the right decisions, the ability of the family to care for sick members, the ability of the family to modify a healthy environment, and the ability of the family to utilize health services) and the implementation of family health tasks with the dependent variable being HIV/AIDS prevention behavior. The analysis was conducted in this study through 9 steps in selecting independent variables that deserve to be included in the multivariate test model as presented in table 24 above. The feasible variable has a significance level (sig.) or p-value $<0.25$ with the "Enter" method in simple logistic regression modeling. The process occurs through oneby-one simple regression analysis stages between each independent variable to the dependent variable. If the results of the table are "variables in the equation" and see the value "sig.". If the significant value is $<0.25$, the variable is eligible to enter the multivariate model. Based on the results of the selection of variables above, the variables which deserve to be included in the multivariate test are the family health task variable in the ability to recognize problems, perform family health tasks, and gender because it has a p-value $<0.25$. 
Table 6. The Most Influential Factors on HIV/AIDS Prevention Behavior in Adolescents in Baros Village, Serang, Banten.

\begin{tabular}{lrrrrr}
\hline Variable & B & Wald & p-value & OR & $(\mathbf{9 5 \%}$ CI) \\
\hline Families know the problem & 0,682 & 7,344 & 0,007 & 1,978 & $1,208-3,239$ \\
\hline Implementation of family health tasks & $-0,366$ & 2,164 & 0,141 & 1 & $0,426-1,129$ \\
\hline Gender & $-0,631$ & 6,292 & 0,012 & 0,532 & $0,325-0,871$ \\
\hline
\end{tabular}

Logistic regression analysis went through several stages, in table 5 above which is the result of a multivariate test after the 9th stage, the results obtained from all independent variables suspected of influencing HIV/AIDS prevention behavior in adolescents in Baros Village, Serang, Banten that there is one sub variable (task family health in the ability to recognize problems) which is most related to HIV/AIDS prevention behavior with p-value $0.007<0.05$. The largest OR value obtained is 1.978 , meaning that families who are unable to recognize the problem are at risk of 1.978 times for the occurrence of poor HIV/AIDS prevention behavior in adolescents in Baros Village, Serang, Banten.

The results of the data distribution display that half of the students of SMA/SMK Attaufiqiyyah, Baros Village, Serang, Banten is the middle age group, which is $77.4 \%$. The sample in this study consisted of high school students in grades 1-3, with an average of students entering their middle and late teens. More than half of the research sample was in the middle age group, in which the middle teens were in grades 1 and 2 of high school. Late teens are less than middle teens because late teens are dominated by 2nd and 3rd grade students. A teenager at the stage of middle adolescence has a character who needs friends, very happy if he has many friends. Furthermore, teenagers begin to like themselves and tend to find friends who have the same nature as them. Adolescents in the late adolescence stage can be implied to have egos that seek opportunities to unite with others and in new experiences.

Gender distribution shows that more than half of the students are female with a percentage of $57.1 \%$. The numbers are not much different. It is because according to the researcher, the number of samples in the sampling who are male and female are almost the same. There is no dominant gender in obtaining the right to education in the school. All genders, both male and female, have the same right to education. Gender inequality occurs when there are different judgments between men and women in a community which causes men and women to get different treatment. It causes inaccuracy in the treatment of adolescents and low ability to access health services.

The distribution of education of fathers and mothers is mostly low education (no school/did not finish elementary/elementary/junior high school) amounting to $87 \%$ of fathers and $92.2 \%$ of mothers. Educational factors determine whether or not someone easily absorbs knowledge. The level of education can affect a person's health behavior including the ability to prevent HIV/AIDS (Notoatmodjo, 2010; Soetjiningsih, 2010). The condition of a high educational background allows parents to more easily receive all information from outside, especially about good family care, how to maintain their children's health, education and others (Handono \& Bashori, 2013).

The distribution of family income levels is less than Rp. 3,872,551.00 as many as 93.6\% have family incomes less than the UMK. Low-income levels affect parents' access to increase knowledge in HIV/AIDS prevention. Soekanto, (2012) mentioned that a person's occupation and education also affect the socioeconomic status of the family. In society, there are several layers of society including the lower, middle, and upper social layers. Each layer of society is certainly different, one of which is influenced by the socioeconomic status of a family. Family income will affect the quality of life of family members. Family income is an important aspect for the family 
and affects family life. Maulina, et al., (2014) suggested that families who have sufficient income can change the health status of the family. It means that families with sufficient income will be better able to facilitate family members in improving family health, in this case increasing knowledge in HIV/AIDS prevention.

The distribution of adolescent ethnicity is mostly ethnically other than Javanese, Sundanese, and Betawi, (64.6\%). Tribe is part of culture. The level of knowledge is influenced by culture, which includes ideas that exist in the human mind and are implemented in everyday life. Each tribe has different customs and norms. The perspective and mindset of a person in behaving towards health is influenced by ethnicity and culture. Culture is a complex whole consisting of knowledge, beliefs, arts, morals, customs, and abilities acquired by a person as a member of society (Isniati, 2012).

Family is tremendously influential for every individual. The family environment is where a person experiences a process of growth and development. Family structure relates to family support for individuals in performing health behaviors. Family support is also associated with a person's quality of life. Relationships between family members have a profoundly strong influence on family members, both physically and psychologically. Undaru, et al., (2015) emphasized that family emotional support can increase the positive impact and reduce the negative impact to improve the quality of life in healthy behavior.

The results of the research on the perception of social support were $48.4 \%$, which were 167 people who had negative perceptions and 51.6\%, which were 178 people who had positive perceptions. The perception of social support for adolescents in Baros Village, Serang, Banten can be identified in the results of the study that more or less have a positive perception. This result is in accordance with research of Sari, (2018) which revealed that the difference between negative and positive perceptions is very small. It is because there are 6 components that form perceptions, comprising of: adolescent beliefs that HIV/AIDS is the result of certain behaviors, adolescents' beliefs about the severity of HIV/AIDS, beliefs about recommended methods of preventing HIV/AIDS, beliefs about the cost of HIV prevention behavior, beliefs about the value of HIV/AIDS prevention behavior, support or encouragement from the surrounding environment in taking actions related to HIV/AIDS prevention behavior, and adolescents' self-confidence in HIV/AIDS prevention behavior (Glanz et al., 2008; Priyoto, 2014).

Likewise, it is emphasized from the theory that the perception of social support is a person's ability to organize and interpret the stimulus he obtains from the environment (Marzuki, 2017). Therefore, Zahra, (2017) stated that the environment which supports the formation of adolescent perceptions is parents, friends and people who are involved in providing and forming a sense of comfort, being loved and appreciated. However, regarding the five components of family health tasks that shape the implementation of family abilities in shaping adolescent behavior, particularly for HIV/AIDS prevention when viewed comprehensively and complexly, it can be stated that there are still more who are unable to conduct family health tasks for adolescents in Baros Village, Serang, Banten.

The developmental conditions that adolescents go through make their behavior tends to be at risk of adopting the behavior of others. Adolescent behavior can be assertive if it can fulfill its developmental tasks. If adolescents do not fulfill their developmental tasks, there will be role conflict which results in adolescents having a weakness in personality so that they are easy to adopt negative behavior (Priasmoro, et 
al., 2016). Likewise, Dewi, (2012) stated that adolescents will go through a stage of egocentrism which is strongly influenced by their social environment, especially peers, family, and teachers.

The results of the bivariate analysis presented that there was no significant relationship between age and HIV/AIDS prevention sexual behavior, nor was there a significant relationship between gender and HIV/AIDS prevention sexual behavior. It is not in accordance with the research result of Martilova, (2020) which discovered that there is a significant relationship between adolescent age and adolescent knowledge in HIV/AIDS prevention. A person's knowledge is influenced by age, increasing a person's age affects his physical and psychological changes. In this study, there was no relationship between age and HIV/AIDS prevention behavior because there were no differences in the values conducted for the existence of a male and female adolescent, so that the treatment was the same for boys and girls.

Mubarok, (2011) argued that adolescents aged more than 17 years have better knowledge than adolescents aged less than 17 years. Middle age adolescents do not necessarily have good or bad behavior in HIV/AIDS prevention, as well as late teens do not necessarily have good or bad behavior in HIV/AIDS prevention. Adolescence is related to the socialization of adolescents with peers which allows them to imitate the behavior of their peers.

The results unveiled that there was a significant relationship between gender and HIV/AIDS prevention behavior in adolescents in Baros Village, Serang, Banten. It is not in accordance with the research of Widyoningsih \& Sutarno, (2017) that gender has no effect on a person's behavior in preventing free sex. Furthermore, there are several things that influence attitudes including personal experience, culture, mass media, important people in their lives, religion, and one's emotions. These are influenced by anxiety factors. Demak, \& Suherman, (2016) emphasized that women have a higher level of anxiety due to excessive autonomic nervous reactions with an increase in the sympathetic system, an increase in norepinephrine, an increase in the release of catecholamines and an abnormal serotonergic regulation disorder. It is in accordance with the results of this study that women have the opportunity greater in HIV/AIDS prevention than men.

The results presented that there was no significant relationship between father's education and HIV/AIDS prevention behavior in adolescents in Baros Village, Serang, Banten. Parents with high education do not necessarily have children with good behavior in preventing HIV/AIDS, and vice versa parents with low education can also have children with good behavior in preventing HIV/AIDS. The condition of a high educational background allows parents to more easily receive all information from outside, especially about good family care, how to maintain their children's health, education and so on (Handono, 2013). Higher education background causes a person to be exposed to the life of modern society so that the individual will easily accept the development of science and modern health care. Therefore, Kasih, (2016) stated that the attitude of adolescents in preventing HIV/AIDS transmission will increase if there is sufficient knowledge in education in the family.

Stanhope, \& Lancaster, (2015) asserted that one of the environmental risk factors that contribute to vulnerability in a population is socioeconomic status. The condition of poverty or low income is the main cause of family vulnerability to health problems. One's perception will affect one's actions in conducting prevention efforts. Moreover, Iqbal, et al., (2019) explained that people living in urban areas have a secondary level of education and have high knowledge of AIDS. It is also influenced by adolescent peers which is enforced in the results of the research by Rini \& Noviyani, (2019) which states 
that the influence of peers is tremendously significant in preventing bad behavior, including the prevention of HIV/AIDS behavior.

The results display that there was no significant relationship between ethnicity and HIV/AIDS prevention behavior in adolescents in Baros Village, Serang, Banten. Differences in cultural shifts at this time when an individual does not purely behave in accordance with the cultural norms that exist in his tribe. It is contrary to the opinion of Isniati, (2012) that the cultural perspective of health problems is influenced by changes in relations with the community that have an impact on health behavior. In the current era of 4.0, it is possible that social media access to communication is quite strong. Teenagers can access information around the world from various mass media today. It allows teenagers to no longer behave and behave according to the norms and culture of the teenager. In the current era, there is a cultural shift which allows the influence of the mass media at this time to grow stronger than ever before.

The results demonstrated that there was no significant relationship between family income and HIV/AIDS prevention behavior in adolescents in Baros Village, Serang, Banten. Family income is influenced by the work in the family. Family income is influenced by the work in the family. The results of this study are not in accordance with the results of research by Da Costa, et al.,(2014) which illustrates that family income is related to a person's quality of life in the implementation of health behavior. Low family income does not necessarily have bad behavior in HIV/AIDS prevention, as well as high family income does not necessarily have good behavior in HIV/AIDS prevention. It is influenced by several things, including access to social media in the 4.0 era, which can be accessed by teenagers with various conveniences without incurring large costs.

The results showed that there was no significant relationship between perceived social support and HIV/AIDS AIDS prevention behavior in adolescents in Baros Village, Serang, Banten. Romdiyah, (2017) declared that there is a relationship between family support and the behavior of preventing HIV/AIDS transmission. Romdiyah, (2017) specified that support from family members as seen from the family structure makes adolescents more motivated in preventing HIV/AIDS transmission behavior and will decrease their motivation if they do not get support from their families. Family support is required so that it can reduce the risk of HIV/AIDS behavior. The family support demanded for teenagers today is different from before because teenagers are looking for freedom in exploring themselves so that their attachment to their family will be reduced. It is confirmed in the research of Adita, et. al., (2017) which explained that family support is very important in the prevention of HIV/AIDS. Families with adolescents need to adapt in performing family development tasks so that there is no confusion which can lead to the fragility of adolescents' personalities (Priasmoro, et. al., 2016).

It is not in line with research by Sari, (2018) which shows that there is a significant relationship between perception and behavior to prevent HIV/AIDS transmission in Madiun City. Based on research from Rini, \& Noviyani, (2019), it is presented that the results above do not match, there is an influence between perception and adolescent health behavior. A person's behavior is determined by the perception of the seriousness of the HIV/AIDS problem. Thus, the source of information has a positive effect on positive perceptions and will shape good HIV/AIDS prevention behavior. However, it should be noted that sources of information come not only from individuals but also parents, peers, health workers, and school teachers (Apollo, \& Cahyadi, 2012; Rini, \& Noviyani, 2019). Furthermore, perception is formed from 
various sources of information obtained by a person so that it is processed and interpreted to provide direction in healthy behavior (Notoatmodjo, 2012).

The results of this study are in accordance with what was stated by Wahyuningtias, (2019) that there is no family functioning with risky sexual behavior in adolescents. The study revealed that family functions are very diverse and not all are related to risky sexual behavior in adolescents. According to Friedman, et al., (2010), the function of the family in shaping the behavior of family members is more emphasized on the function of family health care, which is the ability of the family to perform health tasks to fulfill the task of growing and developing family members as well as adolescents. It is also perceived from the North American Nursing Diagnosis Association (NANDA) that the role of nurses is very necessary in providing education about risky diseases obtained from sexual intercourse, sexual behavior, about selfrespect, belief in religious beliefs, and other counseling guidance to adolescents.

In multivariate analysis, the largest OR value obtained is 1,978 , meaning that families who are unable to recognize the problem are at risk of 1,978 times for the occurrence of poor HIV/AIDS prevention behavior in adolescents in Baros Village, Serang, Banten. Sulistyowati, (2012) mentioned the cause of the family not being optimal in completing family health tasks due to the low level of family ability in recognizing problems. Therefore, the ability of families to recognize problems is the main basis that determines the implementation of family health tasks. Families who are unable to recognize health problems that occur in family members will find it difficult to prevent health problems and perform health care for family members.

\section{CONCLUSION}

The conclusion of this study is that there is a relationship between gender and family health tasks in recognizing problems with HIV/AIDS prevention behavior in adolescents in Baros Village, Serang, Banten. The factor which primarily influences the behavior of preventing HIV/AIDS is the task of family health in the ability to recognize problems. Researchers hope that adolescents will further enhance their socialization with friends, family, and teachers as well as with people in their environment so that they are able to select and perform positive activities so that they have good perceptions and support in behavior, particularly in the prevention of HIV/AIDS. Moreover, families should pay more attention at home, communicate, and interact with adolescents in order to be able to provide information so that it increases not only knowledge but attitudes and behavior in HIV/AIDS prevention. For community nurses, in particular, conduct health education about HIV/AIDS prevention behavior on a continuous and sustainable basis, not only for adolescents but also for their families and peers as a support system.

\section{REFERENCES}

Adita, K., Demartoto, A., \& Pamungkasari, E. P. (2017). Path Analysis on the Factors Affecting People's Behavior in HIV/AIDS Countermeasure on People Living with HIV/AIDS (PLWHA) in Solo Plus Peer Support Group, Surakarta. Journal of Health Promotion and Behavior, 02(01), 41-54. doi: https://doi.org/10.26911/thejhpb.2017.02.01.04

Apollo,. \& Cahyadi, A., . (2012). Konflik Peran Ganda Perempuan Menikah Yang Bekerja Ditinjau Dari Dukungan Sosial Keluarga dan Penyesuaian Diri. Widya Warta, 000(2), 230-239.

Da Costa, T. L., De Oliveira, D. C., Gomes, A. T., \& Formozo, G. A. (2014). Quality of life and people living with AIDS: Relationship with sociodemographic and health 
Ratnawati, D., \& Anggraini, N. V. (2021). The Influence of Perceptions of Social Support and Family Helath Tasks on HIV/AIDS Prevention Behavior in Adolescents. JURNAL INFO KESEHATAN, 19(2), 110-124. https://doi.org/10.31965/infokes.Vol 19/ss2.518

123 aspects. Revista Latino-Americana de Enfermagem, 22(4), 582-590. doi: https://doi.org/10.1590/0104-1169.3350.2455

Demak, I. P. K., \& Suherman, S. (2016). Hubungan Umur, Jenis Kelamin Mahasiswa Dan Pendapatan Orang Tua Dengan Tingkat Kecemasan Pada Mahasiswa Pendidikan Sarjana Program Studi Pendidikan Dokter FKIK Universitas Tadulako. Medika Tadulako: Jurnal Ilmiah Kedokteran Fakultas Kedokteran dan Ilmu Kesehatan, 3(1), 23-22.

Dewi, A. P. (2012). Hubungan Karakteistik Remaja, Peran Teman Sebaya Dan Paparan Ponografi Dengan Perilaku Seksual Remaja Di Kelurahan Pasir Gunung Selatan Depok. Thesis. Fakultas Keperawatan, Universitas Indonesia.

Dinas Kesehatan Provinsi Banten. (2011). Profil Kesehatan Provinsi Banten Tahun 2011. Dinas Kesehatan Provinsi Banten.

Friedman, M. M., Bowden, O \& Jones, M., . (2010). Buku Ajar Perawatan Keluarga: Riset, Teori dan Praktik (5th ed.). Jakarta: EGC.

Glanz, K., Rimer, B. k., \& Viswanath, K. (2008). Health Behavior and Health Education: Theory, Research, and Practice (F. by C. T. Orleans (ed.); 4th ed.). Jossey-Bass A Willey Imprint.

Handono, O., \& Bashori, K. (2013). Hubungan Antara Penyesuaian Diri Dan Dukungan Sosial Terhadap Stres Lingkungan Pada Santri Baru. EMPATHY Jurnal Fakultas Psikologi, 1(2), 79-89.

Iqbal, S., Maqsood, S., Zafar, A., Zakar, R., Zakar, M. Z., \& Fischer, F. (2019). Determinants of overall knowledge of and attitudes towards HIV/AIDS transmission among ever-married women in Pakistan: Evidence from the Demographic and Health Survey 2012-13. BMC Public Health, 19(1), 1-14. doi: https://doi.org/10.1186/s12889-019-7124-3

Isniati. (2012). Kesehatan Modern Dengan Nuansa Budaya. Jurnal Kesehatan Masyarakat, 7(1), 39-44.

Kasih, L. C. (2016). Efektifitas Peer Education Pada Pengetahuan Dan Sikap Siswa SMA Dalam Pencegahan HIV/AIDS. Jurnal Ilmu Keperawatan, 4(2), 26-33.

Kementerian Kesehatan Republik Indonesia. (2018). Hasil Utama Riset Kesehata Dasar (RISKESDAS) 2018. Jakarta: Kementerian Kesehatan Republik Indonesia.

Kementerian Kesehatan Republik Indonesia. (2014). Profil Kesehata Indonesia 2014. Jakarta: Kementerian Kesehatan Republik Indonesia.

Martilova, D. (2020). Faktor Pengetahuan Remaja Dalam Pencegahan HIV/AIDS. JOMIS (Journal of Midwifery Science), 4(1), 63-68. doi: https://doi.org/10.36341/jomis.v4i1.1072

Marzuki,A. (2017). Persepsi dukungan sosial orang tua dengan kreativitas dalam belajar pada siswa kelas VIII di madasrah Tsanawiyah Negeri (MTsN) 1 Palembang. Skripsi. UIN Raden Fatah Palembang.

Maulina, E. I., Makhfudli, M., \& Ulfina, E. (2014). Perbedaan Peran Ibu Dalam Stimulasi Perkembangan Anak Usia Prasekolah Pada Ibu Bekerja Dan Tidak Bekerja Di Wilayah Kerja Puskesmas Banyu Urip Surabaya. Indonesian Journal of Community Health of Nursing, 3(1), 52-56. doi: https://doi.org/http://dx.doi.org/10.20473/ijchn.v3i1.12209

Mubarok, W.I. (2011). Promosi Kesehatan untuk Kebidanan. Jakarta: Salemba Media.

Notoatmodjo. (2012). Promosi Kesehatan dan Perilaku Kesehatan. Jakarta: Rineka Cipta.

Notoatmodjo. (2010). Metodologi Penelitian Kesehatan. Jakarta: Rineka Cipta.

Priasmoro, D. P., Widjajanto, E., \& Supriati, L. (2016). Analisis Faktor-Faktor Keluarga 
Yang Berhubungan Dengan Perilaku Agresif Pada Remaja di Kota Malang dan Pendekatan Teori Structural Fungsional Keluarga. Jurnal Ilmu Keperawatan, 4(2), 114-126.

Priyoto. (2014). Teori Sikap dan Perilaku dalam Kesehatan dilengkapi dengan Contoh Kuesioner. Yogyakarta: Nuha Merdeka.

Rini, A. S., \& Noviyani, E. P. (2019). Konfirmasi Lima Faktor yang Berpengaruh terhadap Perilaku Remaja dalam Pencegahan HIV/AIDS. Jurnal Ilmiah Kebidanan Indonesia, 9(4), 138-153. doi: https://doi.org/10.33221/jiki.v9i04.407

Romdiyah. (2017). Analisis Perilaku Pencegahan Penularan HIVAIDS Pada Ibu Hamil di Puskesmas Kalikajar 1 Wonosobo. Jurnal Ilmiah Kebidanan Indonesia, 8(2), 67-79.

Sari, W. N. (2018). Hubungan Persepsi Waria Tentang HIV/AIDS Tentang Perilaku Pencegahan Penularan HIV/AIDS Di Kota Madiun. Skripsi. Program Studi Sarjana Ilmu Keperawatan, STIKES Bhakti Husada Mulia Madiun.

Soekanto, S. (2012). Sosiologi Suatu Pengantar. Jakarta: PT. Raja Grafindo Persada.

Soetjiningsih. (2010). Tumbuh Kembang Remaja dan Permasalahannya. Jakarta: Sagung Seto.

Stanhope, M., \& Lancaster, J. (2015). Public Health Nursing Population-Centered Health Care in the Community (9th ed.). St. Louis, United States: Mosby.

Sulistyowati, N. (2012). Hubungan Pelaksanaan Tugas Kesehatan Keluarga dengan Kekambuhan Skizofrenia di Desa Paringan Kecamatan Jenangan Kabupaten Ponorogo. Skripsi. Fakultas Keperawatan, Universitas Airlangga.

Undaru, S. B., Cherian, A. V., Bhat, A., Chapman, H. J., Lukose, A., Patwardhan, N., Satyanarayana, V., \& Ramakrishna, J. (2015). Factors affecting psychosocial well-being and quality of life among women living with HIV/AIDS. Journal of Health and Allied Sciences NU, 05(04), 066-076. doi: https://doi.org/10.1055/s0040-1703938

Wahyuningtias, S. E, . (2019). Keberfungsian Keluarga Dengan Perilaku Seksual Berisiko Pada Remaja Di Kecamatan Sumbersari Kabupaten Jember. Skripsi. Program Studi Ilmu Keperawatan, Fakultas Keperawatan, Universitas Jember.

Widyoningsih \&, \& Sutarno. (2017). Hubungan Jenis Kelamin Dengan Sikap Terhadap Seks Bebas. Viva Medika, 10(1), 106-110.

World Health Organization. (2012). Prevention and Treatment of HIV and Other Sexually Transmitted Infections for Sex Workers in Low- and Middle-Income Countries: Recommendations for a Public Health Approach. Geneva: World Health Organization.

Zahra, F. I. (2017). Hubungan Antara Persepsi Dukungan Sosial Dengan Kesejahteraan Psikologis Pada Narapidana Di LPKA Klas 1 Blitar. Skripsi. Fakultas Ilmu Sosial dan Politik, Universitas Brawijaya. 